\title{
EXCURSION TO LEEDS AND THE LOOSE VALLEY (KENT).
}

\author{
Saturday, i8th June, igio. \\ Director: F. J. Bennett, F.G.S. \\ Exarsion Secretary: A. H. Wilirams. \\ (Report by The Director.)
}

A PARTy of some 22 arrived at Hollingbourne Station about I o'clock. The Director explained that they were visiting the eastern end of a very remarkable area, as he considered, of which they had visited part of the western end on the last excursion he directed, on July roth, Igo9. Looking at the map (Plate IX, opp. page 242) they would see that the area was a peninsula, 4 miles east and west, by 2 miles north and south, formed by the rivers Medway, Len and Loose, the two latter joining the Medway south and east of Maidstone.

It is just possible that there may be an underground water connection between the head of the Loose at Langley and that of the mill stream at Leeds, which joins the Len north of Leeds, and that in a sense the area may be an island.

In this area he had found 55 holes, termed by him swallow holes, and eight of these were on the Hythe Bed plateau and on or near the watershed between the Len and the Loose. He stated that there was another such swallow-hole area, a much more compact one, at West Malling, which some day the Association might care to visit. The holes admitted of division into three, or perhaps four, stages.

First Stage.-These were on the plateau and could not be visited last year.

Second Stage.-Those just within the valley, as Bogie Wood Hole, and those they would also see in the Leeds Valley, a gorge at the upper end.

Third Stage.-Those along the bottom of a valley, as those at the bottom of the Willington or Otham Valley, $\mathrm{I} 3$ in number. This valley, as pointed out by him on the last excursion, he considered to be still in the swallow-hole stage, and thus left incompleted. At the end of this valley are caverns, riverformed, and left dry by the water having perhaps suddenly left the valley. That this Willington Valley may still contain an invisible stream seems proved by the fact that the upper hole still contains water, also one near the middle of the valley, 
while at the very bottom is a pool which may be fed by the same underground stream.

Fourth Stage.-This may be represented by the pools along the course of the Loose, once swallow holes. Though most of these holes are dry, yet as some contain water, and thus are true swallow holes and yet cannot be separated from those which are dry, he has termed them all swallow holes.

For the benefit of those who had not heard his views on the initiation of valleys by means of swallow holes, aided by the upward action of water under pressure, when the area afterwards occupied by the valley was under artesian conditions, the Director restated his views which alone had reference to those valleys formed in porous, soluble, water-bearing strata.

Trite as the statement may sound, that you could not begin to understand the formation of any valleys until you could bring the mind back to the time when there was no valley, still, such a mental feat was absolutely necessary ; and yet, simple as this seemed, the ever present valley loomed up as a delusive factor, and was constantly in the way.

In just the same way, the ever present river in these strata, such as the Loose, was constantly in the way and was deluding one to consider that the valley was formed, according to the usual views, by the visible stream alone.

The Director, however, held that in these strata the underground water had been the eroding force long before the visible stream had made it appearance, and that the channel of the subaërial stream had been formed by subsidence, over that one long before marked out underground. ${ }^{*}$ That in this subsidencechannel the subaërial stream then began its course, cutting down through the top impervious cover until it let loose the underground water under pressure, which rose up through lines of weakness, and that the swallow holes were such weak spots. In process of time, of course, when the visible and invisible streams coincided and became one, the whole of the work appeared to be done by the subac̈rial stream, but this, when all the facts above stated were taken into consideration, could not have been the case. A frozen soil-cap too, it must be conceded, must also act as an impervious cover, and intermittently so when thawed and again frozen.

Another interesting feature was the complementary valleys, as he termed them. Thus the south to north mill stream from Leeds to the Len had a complementary or north to south one meeting it; starting from near the top of the Chalk escarpment and between Leeds and Bearstead, to mention one case only, there were two such to the west, in the short distance of two miles. He ventured to suggest that the precursor of those two complementary valleys was a once continuous south to north valley, off the Wealden axis

\footnotetext{
* See the footnote, ante, page 242 .
} 
of elevation, and that this valley had left a line of weakness followed afterwards by the two complementary streams in question. Another interesting fact he would also like to mention was this, that all along the lines of junction in that area, from say, Harrietsham to Otford, he had found when retracing these lines on the 6-in. map that at intervals along the junction between the Chalk and the Gault, between that and the Greensand and between the latter and the Hythe Beds, there were permanent pools, often in well-defined basins. Could these represent former swallow holes? This was, of course, largely speculative, still it was a new fact, well worth recording, and of much interest. Again, too, on the Hythe plateau were many permanent pools or ponds, these might be regarded by some as forms of Dew Ponds and might be connected with the former extension of the Sandgate Beds over the Hythe Beds. Then there was the matter of the gravel, termed by him a "twin-plateau gravel." This was a high-level gravel found by him both at the Folkestone and Hythe plateau, such as that near Leeds Church, etc., which could not be distinguished from the Chalk plateau gravel, and, like this, it contained, but very sparsely, rude flint implements, often with a deep ferruginous stain. Could this have been let down vertically, by solution of the Chalk, when the Chalk still stood over the Hythe Beds? He could see they would object that the Gault could not have been dissolved in the same way. $\mathrm{He}$ would then ask them how had the Gault, etc., been got rid of if it had overlain the Hythe Beds, as the Chalk must have done? This, surely, was a problem that demanded their serious attention. But having had by this time quite enough of such speculative problems the Director led the way to the various points of interest mentioned in the programme. Unfortunately, time did not permit of all these being visited, though close by.

After lunch, the first objective was a quite new section, made to get fuller's earth, half a mile north of Leeds, a section of much importance and involving many points of great interest. Whether intentional or not, for many trial shafts had been made, the spot occupied by the section showed a most unexpected anticline bringing up the Atherfield Clay, with a very sharp rise on the north with the Hythe Beds nearly vertical, while a lesser rise on the south reveals the other part of the anticlinal, all within a space of about 50 yds.

The Atherfield Clay here worked for fuller's earth shows a maximum thickness of about $30 \mathrm{ft}$; this may, perhaps, include some Weald Clay, brought up also to the west, at Caring.

A transverse east and west section, about $30 \mathrm{yds}$. wide, $\mathrm{I}_{4} \mathrm{ft}$. high, seems all in a stony, loamy drift, with beds of sand and gravel, the latter developed more on the north slopes, but these are being earthed and obscured. This loam in one place to the 
east shows a lenticular mass of clay with small pockets of chalk, as if derived from the denudation of Chalk to the north, and suggesting glacial action. 'The gravel, too, is contained in a pellety chalky matrix with manyochreous flints, some rudely worked of early palæolithic or eolithic character, suggestive also of a northern chalk-plateau or scarp-drift origin. This gravel contains some bones, but of the few seen none could be identified.

This "scarp-drift" gravel, etc., may be termed a high-terrace deposit of the I.en when flowing at a higher level or an older drift worked up by that river. Its occurrence is most difficult to account for, as it is the only example of the kind that has come under the notice of the Director.

This high-level loamy drift caps the top of the anticlinal, and may mask any surface exposure of the Atherfield Clay and quite alters the character of the soil for a small area in the region of the anticline. This anticline, with its clay core, has a marked effect on the contour and causes a distinct and sudden gradient in the road passing south to Leeds, but for a short distance only.

It should be noted that to the north of the section and for some distance before the sudden rise of the northern limb of the anticlinal takes place, the Hythe Beds are nearly, if not quite, horizontal. Truly a most interesting, most suggestive, but a most puzzling section.

This anticlinal seems repeated, but less strongly, perhaps, in the Leeds Valley, where the $\Lambda$ therfield Clay is again brought up holding up the water in the lakelet, partly caused by a dam, in that most picturesque valley.

One-quarter of a mile to the west of this section the Len enters a deep transverse east and west gorge in the Hythe Beds, the only one known to the Director, $A$ visit to this most interesting feature, as also one to the mill stream running in a deep channel, on the banks of which much tufa may be seen, had to be omitted for want of time.

Leeds Church, of much interest, with a very wide and massive Norman tower, wide nave, with splendid chancel and side screens, was next visited.

On the way to the Leeds Valley some most picturesque houses were passed. 'This valley, once the site of an abbey, was then entered, but no true traces of the abbey can be seen, only a shed or two with old stone walls.

Bogic Wood Hole was then visited. It is situated at the head of the eastern termination of the valley, and is one of the Director's crater-shaped "swallow holes." A similar example was seen last year in the Brasted Valley, when Westerham was visited under the guidance of Messrs. Treacher and Martin. Some wanted to suggest that man had some hand in this, and that it might be an old quarry used for building the abbey. The Director admitted that man might have utilised to some extent a natural 


\section{$53^{2}$ \\ EXCURSION TO LEeDS AND THE LOOSE VALley (KeNT).}

hole, but as he had found $\mathbf{5 5}$ of these holes in the area, many of which could not possibly have been quarries, and perhaps only first seen by him, Nature must have been the original quarryman.

The gorge-like head of the western end of the valley was next seen, with its smaller-breached swallow holes, as he termed them. Here again, some wanted to introduce man, instead of, or as well as, nature. But here again the Director pointed out that they must go back in imagination to the time when the valley was being initiated by a series of perfect and unbreached holes, as shown on a large scale in Bogie Wood Hole.

The beauty of this high-lying valley, close up to the 300 feet contour line, where the Hythe Plateau commences, with its lakelet, an ideal place for an abbey, appealed to all; as also the fine view of the Chalk scarp, framed in by the mouth of this lovely valley.

A mile walk across fields brought the party to Langley, or Jacob's Hole, the largest of the swallow holes and situated on the Hythe Bed Plateau and close to the highest point, $357 \mathrm{ft}$. ; east of this is the site of Pudding Basin Hole, now grubbed and cultivated. This parallelogram-shaped Langley Hole, is so concealed by trees as to be easily passed by and is very little known. The sides are almost vertical in places and some $40 \mathrm{ft}$. in depth. In the bottom are many smaller crater-shaped holes. 'The shade afforded from the hot sun by this thickly-wooded ravine was most grateful and all were well rewarded for the steep climb, both into and out of $\mathrm{jt}$.

Some were very much inclined to question the Director's suggestion that this, like the others, had also been formed by water rising from below under pressure, when the water level was once very much higher than now, and also that it was of great geological age. They also found it hard to go back to a former very different state of things, when the Chalk scarp must once have stood not far from the site of the plateau holes. The evidence of this was that further south the Director had failed to find any signs of the presence of Scarp Drift. He pointed out that there it was very hard to find any flints at all, and that most of these had been worked, and he also showed two pieces of chert from the Hythe Beds of an implemental form and which might have been slightly shaped by man.

Time pressing, any visit to the Loose Valley had to be omitted, and only a hurried one paid to the upper wet swallow hole at the head of the Willington and Otham Valley, and the three dry ones below this. One of these, Smuggler's Hole, is a very large one; the two smaller ones close by, though well situated to receive drainage water, are only filled by the overflow of the upper one, which always contains water.

Maidstone was reached at 6.15 , and tea was obtained at the 
Bank Restaurant ; after which a cordial vote of thanks was passed to the Director for a most enjoyable and instructive visit, with hopes of another under his guidance.

\section{REFERENCES.}

Geological Survey Map, Sheet 6, Old Series.

Ordnance Survey Map, Sheet 288 , New Series.

I85I. Murchison, Sir R.-"Flint Drift of S.-E. England." Quart. Gourn. Geol. Soc, vol. vii, p. 349.

1875. Topley, W.-"Geology of the Weald." Mem. Geol. Surv., p. 112.

1908. BennetT, F. J.-"Ightham." Homeland Ássoc., pp. 129.13I.

Igos. "Formation of Villeys in Porous Strata." Geogr. Fourn. xxxii, p. 277 , with maps.

1909. _ - "Excursion to Maidstone, etc.," ante, p. 240.

\section{EXCURSION TO SONNING.}

SATURday, JUNE $25 \mathrm{TH}$, 910.

Director: Llewellyn Treacher, F.G.S.

Excursion Secretary: Miss Johnston.

(Report by The Director.)

Notwithstanding the thunder and rain which prevailed nearly all the afternoon a party of twenty-two assembled at Twyford Station about 3 o'clock and drove by the Reading road to Charvil Hill gravel pit on the west side of the Loddon. The gravel belongs to a broad terrace which extends along the south of the Thames nearly to Reading. What was once a continuation of it occurs at Ruscombe, on the opposite side of the Loddon, and from that place at intervals to Wargrave. The height of this gravel above the river varies from 60 to $70 \mathrm{ft}$., and there is a patch of a similar deposit near Shiplake Church, north of the Thames, at a slightly higher level. Palæolithic implements of mixed types are found abundantly at all these places, and the gravels are probably the remnants of an extensive flood-plain which existed at the junction of the Loddon with the Thames in palæolithic times. The level of the land being stationary for a lengthened period, the rivers cut the floors of their valleys down to base-level and widened them to a great extent, while palæolithic man lived in the country and fashioned his tools by the banks of the meandering streams.

A short halt was made at this pit, but the rain was too heavy for the members to see more than a small part of a not very recently worked section. About fifty implements have been found here during the last twenty years. The gravel rests on 